Vibart, R.E.; Tavendale, M.; Otter, D.; Schwendel, B.H.; Lowe, K.; Gregorini, P.; Pacheco, D. 2017. Milk production and composition, nitrogen utilization and grazing behavior of late-lactation dairy cow as affected by time of allocation of a fresh strip of pasture. Journal of Dairy Science 100: 5305-5318. Vlaeminck, B.; Fievez, V.; Cabrita, A.R.J.; Fonseca, A.J.M.; Dewhurst, R J. 2006. Factors affecting odd- and branched-chain fatty acids in milk: A review. Animal Feed Science and Technology 131: 389-417. Walker, G.P.; Dunshea, F.R.; Doyle, P.T. 2004. Effects of nutrition and management on the production and composition of milk fat and protein: A review. Australian Journal of Agricultural Research 55: 1009-1028.

\section{The implications of winter milk premiums for sustainable profitability of dairy systems}

T.L. CHIKAZHE, K.A. MASHLAN, P.C. BEUKES, C.B. GLASSEY, J. HAULTAIN and M.B. NEAL DairyNZ, Private Bag 3221, Hamilton 3240, New Zealand taisekwa.chikazhe@dairynz.co.nz

\section{Abstract}

Matching seasonal pasture growth to cow demand has been the key to New Zealand's ability to produce milk competitively. However, driven by the need to process milk all year for value-add products like UHT milk, Fonterra has increased the incentive for producing milk in the winter. This has some farmers questioning their spring calving approach and considering calving outside spring to increase profitability of their system using the winter milk premium. In an attempt to answer farmer's questions, modelling was done using OVERSEER $^{\circledR}$ for the environmental footprint and Farmax Dairy for the economic impact of changing the calving season. The objective of the modelling was to highlight key factors that need careful assessment for individual farm situations before deciding to change calving season. Whole farm system modelling was done for Ruakura and Pukekohe pasture growth profiles in the Waikato, and Te Hana and Maungatoroto growth profiles in Northland to consider the implications from both a profitability and environmental perspective. In the four districts modelled results suggest the key drivers for autumn calving profitability are: seasonal pasture growth profile, soil type, winter milk premium and cost of infrastructure/equipment upgrade. Regions with pasture growth profiles that remain profitable after changing from spring to autumn without the winter milk premium are the most ideal, as there is no guarantee the premium will stay at the current level.

Keywords: modelling, winter milk premium, pasture growth profile, profitability, nitrogen leaching

\section{Introduction}

The winter milk premium has been increased to encourage farmers to produce more milk during the winter months, driven by the increased demand for UHT cream in China (Fonterra 2017). As a result, there is a renewed interest among farmers as to whether or not they can take advantage of the increased premium. Autumn calving systems imply a less than ideal match between supply and demand for pasture, therefore, whether they are more profitable is likely to be dependent on the winter milk premium, their ability to source cheap supplements and the capital and transitional cost of changing to autumn calving. The inherent risk

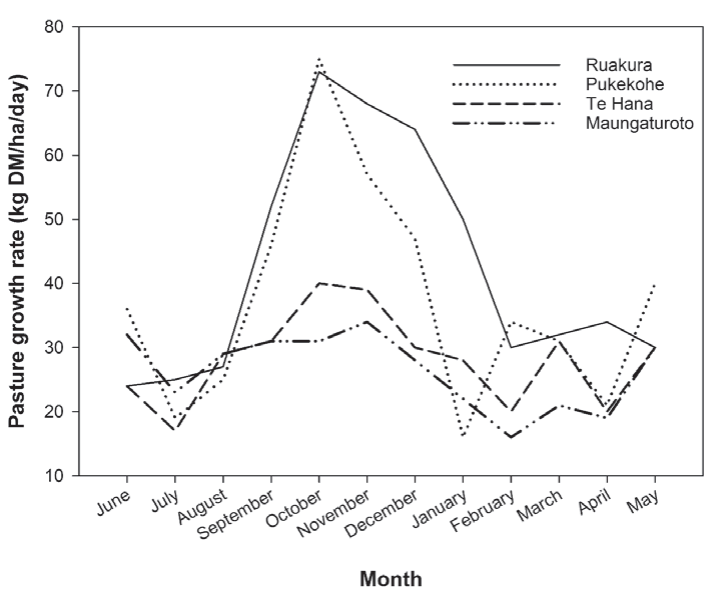

Figure 1 Average monthly pasture growth rates for the four districts.

of changing calving season is that the winter milk premium is not guaranteed to remain at current levels. The objective of this modelling exercise was to reasses profitability of winter milking systems under the current milk price and newly announced milk premium and test profitability on different pasture growth profiles and winter milk premiums. Consequences for nitrogen $(\mathrm{N})$ leaching were also assessed.

\section{Methods}

Typical Waikato and Northland medium input spring calving systems were modelled using 2014/2015 Dairy Statistics (www.lic.co.nz), Economic Survey (www.dairynz.co.nz) and DairyNZ regional systems descriptor data. Medium input can be described as a farm that imports approximately $10-20 \%$ of total feed to the milking area to extend lactation (usually autumn feed), and to feed dry cows (Hedley et al. 2006). Two different pasture growth profiles were chosen. In Waikato, pasture growth data from Ruakura (15.5 $\mathrm{DM} /$ ha/year) and Pukekohe (13.6 t DM/ha/year) were used; in Northland, pasture growth data from Te Hana (10.3 t DM/ha/year) and Maungaturoto $(9.6 \mathrm{t} \mathrm{DM/ha/}$ year) were used (DairyNZ 2010; Figure 1).

For each pasture growth profile, four autumn calving systems were modelled in Farmax Dairy (Bryant $e t$ 
al. 2010, version 7.1.0.21) and OVERSEER ${ }^{\circledR}$ version 6.2.3, and compared for mid-winter (July) calving systems:

1. Split calving (70\% July and 30\% March autumn)

2. Autumn calving - March

3. Autumn calving - April

4. Autumn calving - May

A sensitivity analysis was completed for each autumn calving system based on:

1. Milk price: $\$ 6$ or $\$ 5 / \mathrm{kg}$ milksolids $(\mathrm{MS}=\mathrm{fat}+$ protein)

2. Winter premium: full (current premium), half, or no premium.

A series of key assumptions were used across all scenarios:

1. Spring calving base farms have already a high level of supporting infrastructure in place i.e. correctly sized feed pad (at least $3.5 \mathrm{~m}^{2} / \mathrm{cow}$ based on usage of 4-5 hours/day), and adequate effluent storage (ponds) to avoid the need to apply effluent when soils are wet and good feed storage with a concrete base.

2. A $\$ 6 / \mathrm{kg}$ MS milk price was used in conjunction with 2014-2015 cost structure, and the currently proposed contracted milk premium, $\$ 2.85 / \mathrm{kg}$ MS for May $16^{\text {th }}$ $31^{\text {st }}, \$ 3.50$ for June and $\$ 2.85$ for July $1^{\text {st }}-15^{\text {th }}$.

3. The winter milking systems (and the split system on a pro-rata basis) attracted an extra cost of $20 \mathrm{c} / \mathrm{kg}$ MS for depreciation of infrastructure and equipment upgrades. This cost was derived from a DairyBase analysis of winter milking systems in the Waikato.

4. Transitioning costs of shifting from spring to autumn calving were not modelled. However, in the Discussion an assessment of the potential costs of one such a scenario are provided.

5. At least $40-50 \%$ of the cow's diet in winter came from pasture, which avoided too much reliance on imported supplements. Stocking rate was adjusted to achieve shis target. This was achieved by ensuring a biologically feasible scenario in Farmax when 40 $50 \%$ of the herd's winter diet consisted of pasture. More surplus spring pasture was conserved as result of reduced stocking rates.

6. Standard schedule premiums for cull cow sales at different times of the year applied, and no additional premiums were included in calf sales for autum calving scenarios. These additional premiums are not contracted and if winter milking increses there is no guarantee that stock price premiums will remain at the current level.

7. No allowance for differing cow wastage and replacement rates.

8. In all scenarios young stock were grazed off-farm while non-lactating animals were grazed on-farm with the exception of the split calving scenario where nonlactating spring calving cows were grazed off-farm.
Autumn calving cows produced more MS/cow due to longer lactations and higher production in mid- and late-lactation, although peak production was lower than spring calving cows (Table 1). The longer lactations occurred because dry-off and culling decisions are not typically driven by cow condition. Autumn calving cows gan weight during spring when cow intakes are above requirem for milk prodotion. are observations are consistent with other results (Auldist Wit. 1997, Garcia \& Holmes 1999).

With a full winter milk premium, and for both $\$ 5$ and $\$ 6 / \mathrm{kg}$ MS milk prices, operating profit was higher in autumn compared with spring calving systems in all four districts, although this was marginal in the Ruakura district. Across regions the trend was for the highest profit with March and April calving, then May, split and mid-winter (July). In the May calving system May calving system ws have calved by mid-May so there was less milk attracting a premium. Split calving required al spring-calving non-lactating cows to be wintered off, which incurred wintering costs, while only $30 \%$ of the herd attracted the winter milk premium. With half the premium autumn calving was still more profitable than spring calving in the Northland region, while in the Waikato region it was less profitable. Autumn calving was less profitable than spring calving in all districts when no premium was applied (Table 1).

In the Waikato autumn calving systems had substantially higher farm working expenses than spring systems (24-32c/kg MS), mainly because of increased imported supplementary feed for winter. Farm working expenses for autumn calving were similar to spring systems in the Northland region (Table 1) because of a more favourable winter relative to summer growth profile in these regions resulting in less imported winter feed (Figure 1)

In the Northland winter milking resulted in a 1-2 $\mathrm{kg} / \mathrm{ha}$ increase in $\mathrm{N}$ leaching, while in the Waikato $\mathrm{N}$ leaching decreased by $1-4 \mathrm{~kg} / \mathrm{ha}$ (Table 1 )

\section{Discussion}

Modelling results show that profitability of autumn calving compared with spring calving systems are driven by the pasture growth profile of the region and the winter milk premium. Winter pasture gowth rates that are higher relative to summer growth rates (Figure 1) are important for the profitability of autumn calving, because a key aspect of profitability is the amount of imported supplements for winter feeding of cows. The greater the supplement use the higher the average cost of production and the less profitable the system will be. These results align with those from a Massey University trial (Garcia \& Holmes 1999) as well as with results from Northland research farm (Chestnut
Table 1 Modelling results at $\$ 6 / \mathrm{kg}$ MS milk price (unless otherwise indicated) with sensitivity for winter premium. All operating profit (EBIT) results includes additional costs for infrastructure and equipment upgrade for the winter milking systems.

\begin{tabular}{|c|c|c|c|c|c|}
\hline \multirow{2}{*}{ Region/Location } & \multicolumn{5}{|c|}{ Calving system } \\
\hline & July & Split & March & April & May \\
\hline \multicolumn{6}{|l|}{ Waikato } \\
\hline \multicolumn{6}{|l|}{ Ruakura } \\
\hline Stocking rate (cows/ha) & 3.1 & 3.1 & 2.8 & 2.8 & 2.8 \\
\hline Milksolids per ha (kg) & 1273 & 1300 & 1209 & 1199 & 1200 \\
\hline Milksolids per cow (kg) & 412 & 422 & 425 & 422 & 422 \\
\hline Peak milksolids production (kg/cow/day) & 2.01 & 1.92 & 1.77 & 1.86 & 1.89 \\
\hline Farm working expenses (\$/kg MS) & 4.00 & 4.22 & 4.35 & 4.23 & 4.15 \\
\hline Milk revenue with full premium (\$/kg MS) & 5.97 & 6.26 & 6.69 & 6.66 & 6.48 \\
\hline Profit without premium (\$/ha) & 2743 & 2476 & 1937 & 2043 & 2182 \\
\hline Profit with half premium (\$/ha) & 2743 & 2645 & 2356 & 2440 & 2469 \\
\hline Profit with full premium (\$ha) & 2743 & 2812 & 2771 & 2834 & 2754 \\
\hline Profit with full premium ( $\$ / h a)$ (at $\$ 5$ milk price) & 1471 & 1511 & 1575 & 1649 & 1568 \\
\hline $\mathrm{N}$ leaching $(\mathrm{kg} / \mathrm{ha})$ & 35 & 31 & 34 & 32 & 31 \\
\hline \multicolumn{6}{|l|}{ Pukekohe } \\
\hline Stocking rate (cows/ha) & 2.7 & 2.7 & 2.7 & 2.7 & 2.7 \\
\hline Milksolids per ha (kg) & 1127 & 1157 & 1161 & 1154 & 1155 \\
\hline Milksolids per cow (kg) & 412 & 423 & 425 & 422 & 422 \\
\hline Peak milksolids production (kg/cow/day) & 2.02 & 1.95 & 1.75 & 1.81 & 1.88 \\
\hline Milk revenue with full premium (\$/kg MS) & 5.97 & 6.27 & 6.70 & 6.65 & 6.51 \\
\hline Farm working expenses (\$/kg MS) & 4.19 & 4.42 & 4.50 & 4.51 & 4.46 \\
\hline Profit without premium (\$/ha) & 2157 & 1951 & 1690 & 1674 & 1750 \\
\hline Profit with half premium (\$/ha) & 2157 & 2105 & 2098 & 2052 & 2033 \\
\hline Profit with full premium (\$/ha) & 2157 & 2257 & 2502 & 2426 & 2313 \\
\hline Profit with full premium (\$/ha) (at $\$ 5$ milk price) & 1029 & 1098 & 1335 & 1265 & 1148 \\
\hline N leaching (kg/ha) & 39 & 37 & 38 & 38 & 35 \\
\hline \multicolumn{6}{|l|}{ Northland } \\
\hline \multicolumn{6}{|l|}{ Te Hana } \\
\hline Stocking rate (cows/ha) & 2.3 & 2.3 & 2.2 & 2.2 & 2.2 \\
\hline Milksolids per ha (kg) & 719 & 728 & 719 & 719 & 711 \\
\hline Milksolids per cow (kg) & 318 & 322 & 331 & 331 & 327 \\
\hline Peak milksolids production (kg/cow/day) & 1.56 & 1.53 & 1.55 & 1.6 & 1.66 \\
\hline Milk revenue with full premium (\$/kg MS) & 5.97 & 6.21 & 6.69 & 6.58 & 6.36 \\
\hline Farm working expenses (\$/kg MS) & 4.96 & 5.02 & 5.00 & 4.86 & 4.84 \\
\hline Profit without premium (\$/ha) & 743 & 683 & 592 & 682 & 681 \\
\hline Profit with half premium (\$/ha) & 743 & 772 & 851 & 902 & 822 \\
\hline Profit with full premium $(\$ / h a)$ & 743 & 862 & 1111 & 1121 & 962 \\
\hline Profit with full premium (\$/ha) (at $\$ 5$ milk price) & 24 & 133 & 392 & 402 & 254 \\
\hline$N$ leaching (kg /ha) & 16 & 17 & 17 & 17 & 16 \\
\hline \multicolumn{6}{|l|}{ Maungaturoto } \\
\hline Stocking rate (cows/ha) & 2.2 & 2.2 & 2.2 & 2.2 & 2.2 \\
\hline Milksolids per ha (kg) & 687 & 699 & 717 & 716 & 709 \\
\hline Milksolids per cow (kg) & 317 & 323 & 334 & 333 & 330 \\
\hline Peak milksolids production (kg/cow/day) & 1.56 & 1.53 & 1.55 & 1.6 & 1.66 \\
\hline Milk revenue with full premium (\$/kg MS) & 5.97 & 6.21 & 6.69 & 6.58 & 6.37 \\
\hline Farm working expenses ( $\$ / \mathrm{kg} \mathrm{MS}$ ) & 5.11 & 5.20 & 5.17 & 5.04 & 5.00 \\
\hline Profit without premium (\$/ha) & 592 & 528 & 460 & 553 & 577 \\
\hline Profit with half premium $(\$ / h a)$ & 592 & 613 & 718 & 771 & 719 \\
\hline Profit with full premium $(\$ / h a)$ & 592 & 699 & 975 & 989 & 860 \\
\hline Profit with full premium (\$/ha) (at $\$ 5$ milk price) & -99 & -2 & 253 & 267 & 147 \\
\hline N leaching (kg/ha) & 16 & 17 & 17 & 18 & 17 \\
\hline
\end{tabular}


\& Robinson 1999). This point was further emphasised by the fact that operating profit was $65-67 \%$ higher for April autumn calving compared with spring calving in the region with the most favourable growth profile for winter milking (Maungaturoto), compared with a 1-3\% advantage in the region with the least favourable growth profile (Ruakura). Profitability for Ruakura pasture growth profile is not likely to be sustainable if the current winter premium price is reduced. A DairyBase analysis of winter milking compared A Dith cal calving systems for the Waikato region 2014-2015 Group) were showed that on average winter milking systems were less profitable for that year by $\$ 600 /$ ha. However, this analysis was done at a contracted winter milk premium ( $\$ 1.40 / \mathrm{kg}$ MS for 1 May - 31 July), before the latest Fonterra announcement. Winter milking farms on DairyBase did not reduce stocking rate to ensure at least 40-50\% of the cow's diet in winter is from pasture, as a result, they have higher supplementary feed cost. The current premium is not likely to close the $\$ 600 /$ ha difference for these DairyBase farms. With the modelling at least $40-50 \%$ of the cow's diet in winter came from pasture, which avoided too much reliance on imported supplements. Stocking rates were adjusted to achieve this target. Spring calving stocking rates are primarily based on spring and summer pasture growth rates. In the autumn calving scenarios winter growth rates were used to set stocking rates. Thus, for autumn calving scenarios on a pasture growth profile like Ruakura, that grows less pasture in winter relative to spring and summer, large quantities of pasture had to be conserved. This incurred costs and create inefficiencies.

While more milk production in autumn and winter generally leads to an increase in nitrogen leaching, the use of a feed pad during this critical period can reduce or minimise nitrogen leaching (Romera et al. 2017). This concurs undertaken on Daiy NZ's Scott Form, whe the of stand- 0 in of stand-orf in autumn and winter reduced $\mathrm{N}$ leaching by approximately $20 \%$ in one of the farmlets (Selbie et al. 2017). Additionally, moving non-lactating cow off-farm for wintering in the split calving system would reduce nitrogen leaching.

Where infrastructure and/or equipment upgrades are required to change to autumn calving (e.g. to comply with regulations), increased repair and maintenance and depreciation costs can be substantial. Such increases in cost can substantially reduce the profitability of winter milking. According to calculations undertaken by DairyNZ's sustainability team, the volume of effluent storage capacity requirements for split and autumn calving can increase by $40-90 \%$ depending on soil type and rainfall (https://www.dairynz.co.nz/environment/ effluent/effluent-storage/dairy-effluent-storagecalculator-desc/). For some farms this might mean a large investment to meet these requirements.

March and April calving (100\% autumn) were more profitable than split and May when a full winter milk premium was applied. However, calving too early in March could increase the risk of a feed deficit due to a late-summer dry spell. In contrast, when calving late in autumn (e.g. May), a portion of the May premium wo into June. With splir in milk receive any premium, and there are extra costs in wintering the spring-calving dry cows to release onfarm feed for the autumn-calving herd. So, the choice of autumn calving month depends on the balance between coping with climatic risks for a farming area on one hand, and achieving the milk production curve that best captures the winter premium.

Potential costs of transitioning the herd from spring to autumn calving can be substantial. On average, autumn calving cows have a $\$ 200$ premium $/$ cow. For a farm stocked at $3.2 \mathrm{cows} / \mathrm{ha}$ this represents an additional cost of $\$ 640 /$ ha for that transition year, assuming the farm is selling its spring herd and buying an autumn calving herd. However, there are a number of possible options for transitioning and these should be evaluated both for financial feasibility and risk level. Each has a financial cost that could reduce the profits from the first few years of winter milking.

Another important factor in determining the likely success of autumn calving system is soil type. Heavy soils can result in poor pasture utilisation during wet periods and increased reliance on imported supplements. This situation is more likely in autumn calving systems because cows are milked through the wet period.

As typical medium input farms with adequate infrastructure for four districts and growth profiles in Waikato and Northland were modelled, the results cannot be generalised across all regions. The importance of factors like individual farm pasture growth curves, soil type and transition costs (which were not modelled), emphasises the need for farm specific analyses before considering changing to winter milking.

\section{Conclusion}

Some farms may increase their profitability by changing from spring to autumn calving, but this is more likely to be sustainable in regions that experience dry summers and grow more pasture in winter than summer, have free draining soils, and where no substantial upgrades in equipment and infrastructure are required. A sustainable autumn calving system could be considered robust when the winter growth rates allow a profitable winter milking system even without a win premium. Farms that need the current winter milk premium to sustain profitability are exposed to risk of lower future premiums and changing back to spring calving can also be costly. The current premium is driven by one product, UHT cream, sold to China. To make an informed decision whether or not to change calving season, farmers must have solid knowledge of their pasture growth profile, feed sources and costs, and carefully assess the costs involved in changing the herd's calving dates, equipment and infrastructure, labour requirements, and complete a full sensitivity analysis of potential winter premium prices.

\section{ACKNOWLEDGEMENTS}

This work was funded by New Zealand dairy farmers through DairyNZ.

\section{REFERENCES}

Auldist, M J · Walsh, B J.; Thomson, N.A. 1997. Effects of time of calving on dairy production. Proceedings of New Zealand Society of Animal Production 57. 204-206.

Bryant, J.R.; Ogle, G.; Marshal, P.R.; Glassey, C.B.; Lancaster, J.A.S.; Garcia, S.C.; Holmes, C.W. 2010. Description and evaluation of Farmax Dairy-pro decision support model. New Zealand Journal of Agricultural Research 53:13-28

Chestnutt, K.; Robinson, K. 2001. Winter milk - an overview of the Northland experience. Proceedings of the $53^{\text {rd }}$ Ruakura Farmers' Conference: 61-63.

DairyNZ. 2010. Facts and figures for New Zealand dairy farmers.

Fonterra. 2017. Winter milk handbook. 13pp.

Garcia, S.C.; Holmes, C.W. 1999. Effects of time of calving on the productivity of pasture-based dairy systems. A review. New Zealand Journal of Agricultural Research 42: 347-362.

Hedley, P.; Kolver, E.; Glassey, C.; Thorrold, B.; van By, P. Kolver, E.; Glo, J, Macdontd, $\mathrm{K}$ Achieving high performance from a range of farm systems. Proceedings of the $4^{\text {th }}$ Dairy 3 Conference, Hamilton, New Zealand: 147-166.

Romera, A.J.; Cichota, R.; Beukes, P.C.; Gregorini, P.; Snow, V.O.; Vogeler, I. 2017. Combining restricted razing and nitrification inhibitors to reduce nitrogen leaching on New Zealand dairy farms. Journal of Environmental Quality 46: 72-79.

Selbie, D.R.; Shepherd, M.; Hedley, M.; Macdonald, K.; Chapman, D.; Lucci, G.; Shorten, P.; Welten, B Pirie, M.; Roach, C.; Glassey, C.; Beukes, P. 2017. Following the nitrogen: explaining the reasons for decreased $\mathrm{N}$ leaching in the Waikato P21 farmlets. Science and policy: nutrient management challenges for the next generation. Eds. Currie L.D.; Hedley M.J. Occasional Report No. 30. Fertilizer and Lime Research Centre, Massey University, Palmerston North, New Zealand. 5pp

http://flrc.massey.ac.nz/publications.html. 